\title{
SOLIDARNOŚĆ, EKWIWALENTNOŚĆ CZY SPRAWIEDLIWOŚĆ? ZARZĄDZANIE WIEKIEM EMERYTÓW W POLSKIM POWSZECHNYM SYSTEMIE EMERYTALNYM
}

\author{
Jan Sikora' ${ }^{1}$, Leszek Wanat ${ }^{2}$, Iwona Widerska ${ }^{3}$ \\ ${ }^{1}$ Uniwersytet Zielonogórski, Wydział Ekonomii i Zarządzania \\ ${ }^{2}$ Collegium Da Vinci w Poznaniu, Wydział Nauk Społecznych \\ ${ }^{3}$ Uniwersytet Ekonomiczny w Poznaniu, Wydział Ekonomii
}

\begin{abstract}
Streszczenie: W pracy podjęto próbę analizy uwarunkowań społeczno-gospodarczych dotyczących zarządzania wiekiem emerytalnym w powszechnym systemie ubezpieczeń społecznych w Polsce. Za punkt wyjścia przyjęto zasadę, zgodnie z którą w polskim systemie ubezpieczeń o prawie do emerytury decyduje ukończenie wyznaczonego wieku oraz wykazanie i udokumentowanie określonego przepisami prawa okresu ubezpieczenia. Tło analizy stanowią uwarunkowania ekonomiczne, demograficzne i prawno-organizacyjne, obowiązujące w Polsce na koniec roku 2017, widziane z perspektywy nauk o zarządzaniu. Uwzględniając wybrane czynniki, w tym długość okresu ubezpieczenia oraz wysokość kapitału zgromadzonego przez ubezpieczonych, zweryfikowano pytania o ekwiwalentność, solidarność i sprawiedliwość powszechnego systemu emerytalnego w Polsce. Bazując na danych wtórnych statystyki publicznej OECD, GUS i ZUS, posłużono się metodami analizy porównawczej i deskryptywnej. W konkluzji sformułowano rekomendacje dla polityki społecznej.
\end{abstract}

Słowa kluczowe: zabezpieczenie społeczne, system emerytalny, zarządzanie wiekiem eme-rytalnym, Polska

DOI: $10.17512 /$ znpcz.2018.1.12

\section{Wprowadzenie}

Powszechne prawo do emerytury oraz reguły wyznaczania wysokości świadczeń stanowią jedno $\mathrm{z}$ zadań polityki społecznej państwa, a równocześnie przedmiot zainteresowania przyszłych i obecnych beneficjentów systemu emerytalnego. Sytuacja społeczna, określona przynależnością do starego, przejściowego, bądź nowego scenariusza systemu emerytalnego, determinuje postawy i oczekiwania interesariuszy. Problematyka zarządzania wiekiem emerytalnym to wrażliwy przedmiot nie tylko debaty naukowej, ale również polemiki społeczno-politycznej (Samborski 2011; Urbaniak 2011; Stachowska 2012; Woszczyk 2013).

Różnicowanie wieku przyszłych emerytów stanowi wypadkową czynników obiektywnych, w tym trwałych zmian demograficznych oraz nierównowagi na rynku pracy, a także subiektywnych, zwłaszcza poziomu i jakości życia społeczeństwa oraz jego ekonomiczno-społecznych uwarunkowań (Liwiński, Sztanderska 
2010; Zięba 2014; Lubrańska 2016). Zwraca się uwagę na konieczność aktywizacji różnych grup wiekowych, a zwłaszcza ludzi młodych, na rynku pracy (Kołodziejczyk-Olczak 2014; Rogozińska-Pawełczyk 2014).

Bez wiedzy, niezbędnej do oceny uwarunkowań zabezpieczenia społecznego, a zarazem umożliwiającej identyfikację potencjalnych konsekwencji funkcjonowania powszechnego systemu emerytalnego w różnych jego odmianach, próba racjonalnej dystrybucji świadczeń emerytalnych wydaje się zadaniem trudnym (Wanat, Potkański 2010). Z tychże powodów podjęto w pracy próbę identyfikacji uwarunkowań zarządzania wiekiem emerytów w Polsce, odnosząc się do systemu obowiązującego na koniec roku 2017. W tym kontekście dokonano oceny przyjętych regulacji prawnych $\mathrm{w}$ zakresie ubezpieczeń społecznych, widzianych $\mathrm{z}$ perspektywy interesariuszy starego, przejściowego oraz docelowego systemu emerytalnego. Sformułowano pytanie badawcze, istotne z punktu widzenia polityki społecznej państwa - o ekwiwalentność, solidarność i sprawiedliwość powszechnego systemu emerytalnego w Polsce. Adekwatność tych czynników zweryfikowano, bazując na statystycznych danych wtórnych OECD (2015), GUS (2015) i ZUS, korzystając z metod analizy retrospektywnej, komparatywnej i deskryptywnej.

\section{Cechy polskiego systemu emerytalnego}

Polski system emerytalny charakteryzują dwie perspektywy: świadczeniowa oraz zaopatrzeniowa. Systemem tym objęto pracowników najemnych, pracujących na własny rachunek, rolników, służby mundurowe oraz sędziów i prokuratorów. Równolegle do powszechnego systemu ubezpieczeń społecznych, którego administratorem jest Zakład Ubezpieczeń Społecznych (ZUS), funkcjonuje system ubezpieczenia społecznego rolników, zarządzany przez Kasę Rolniczego Ubezpieczenia Społecznego (KRUS), a także branżowe systemy zaopatrzeniowe (policja, wojsko, Agencja Bezpieczeństwa Wewnętrznego, Służba Wywiadu Wojskowego, Centralne Biuro Antykorupcyjne, Biuro Ochrony Rządu, Państwowa Straż Pożarna, Straż Graniczna, Służba Więzienna, prokuratorzy i sędziowie). Powszechny (państwowy) system emerytalny jest otwartym, dwufilarowym systemem o charakterze repartycyjno-kapitałowym. Koszty jego funkcjonowania ponoszą podatnicy, a beneficjentami systemu są ubezpieczeni oraz emeryci.

W roku 1999 rozpoczęto reformę dotychczasowego, pracowniczego systemu emerytalnego. System repartycyjny o zdefiniowanym świadczeniu (defined benefit system) zastąpiono rozwiązaniem trójfilarowym (defined contribution system), o ściśle zdefiniowanej składce. Prawo do emerytury przyznano pracownikom najemnym, samozatrudnionym oraz przedsiębiorcom, których objęto ubezpieczeniami obowiązkowymi: emerytalnym i rentowym. Tak skonstruowany mieszany model obowiązkowego ubezpieczenia emerytalnego miał $\mathrm{z}$ zasady zapewnić finansowe bezpieczeństwo beneficjentom. Podkreślano, że odpowiedzialność państwa za zabezpieczenie emerytalne stanowi konsekwencję obowiązku odprowadzania składek, które winny pokryć, przynajmniej potencjalnie, zobowiązania wobec przyszłych emerytów (Olejnik 2016, s. 37). 
Analiza zasad funkcjonowania systemu zdefiniowanej składki pozwala na wykazanie ścisłego związku z uzyskaniem prawa do świadczenia po ukończeniu podstawowego wieku, gdzie wysokość świadczenia zależy bezpośrednio od sumy wpłaconych składek. Oznacza to, że potencjalnemu emerytowi przysługuje kapitał w takiej wysokości, jaką stanowi suma składek odprowadzonych na ten cel w okresie jego pracy zawodowej, uwzględniając zarazem wskaźnik średniego dalszego trwania życia. Ewentualne późniejsze przejście na emeryturę wynagradzane jest w tej formule poprzez wzrost kwoty świadczenia emerytalnego.

Definiując polski system emerytalny, w jego pierwszych dwóch filarach dokonano wyodrębnienia indywidualnych kont emerytalnych, na których ewidencjonowane są składki. W pierwszym filarze podlegają one systematycznej waloryzacji, nie są dziedziczone, trafiając do budżetu państwa. Stopa ich waloryzacji zależy od wysokości średniego wynagrodzenia oraz od liczby opłacających te składki.

Dla porównania - w starym systemie ubezpieczeń pracowniczych o prawie do emerytury decydował fakt ukończenia powszechnego wieku emerytalnego oraz przepracowania określonej liczby lat (odpowiednio 20 lat dla kobiet oraz 25 lat dla mężczyzn). Wysokość świadczenia zróżnicowano, uzależniając od wielu parametrów, powiązanych $\mathrm{z}$ wkładem własnym pracownika (część stażowa i podstawa wymiaru emerytury) oraz od niego odrębnych (część socjalna).

Ponadto, w tak zwanym systemie przejściowym (2009-2014), prawo do emerytury określanej mieszaną uwarunkowano ukończeniem wieku emerytalnego oraz udokumentowaniem jakiegokolwiek stażu (okresu) pracy. W tej konstrukcji fakt legitymowania się krótkim okresem ubezpieczenia nie przesądzał o wysokości świadczenia. Emerytura mieszana stanowiła bowiem sumę określonych części „starej” oraz „nowej” emerytury (ich udział procentowy uzależniono od daty nabycia prawa do świadczenia).

$\mathrm{W}$ polskim systemie ubezpieczeń prawo do świadczenia powstaje w momencie osiągnięcia podstawowego wieku emerytalnego, pod warunkiem udowodnienia prawa do tegoż ubezpieczenia. Emeryturę beneficjenta nowego systemu oparto, przynajmniej z definicji, na zasadzie ekwiwalentności (Szumlicz 2010, s. 162), czyli proporcjonalnej zależności między opłaconymi uprzednio składkami a należną (otrzymaną) w przyszłości kwotą emerytury. Rozwiązanie to równocześnie uznaje się za sprawiedliwe, gdyż uwzględnia indywidualną odpowiedzialność beneficjenta za finansowanie swojego przyszłego utrzymania, motywując do wydłużania okresu zawodowej aktywności. O wysokości tak określonej emerytury decyduje kwota składek zgromadzona na koncie ubezpieczonego oraz średnie dalsze trwanie życia. Im wyższa kwota (suma) składek emerytalnych (podlegających waloryzacji wskaźnikiem rocznym i kwartalnym (w PLN)) oraz niższy wskaźnik (okres) średniego dalszego trwania życia (w miesiącach), tym potencjalnie wyższa będzie kwota emerytury.

W systemie takim gwarantowana jest emerytura stanowiąca przynajmniej równowartość kwoty minimalnego świadczenia, dla kobiet legitymujących się okresem 20 lat pracy oraz mężczyzn wykazujących odpowiednio 25-letni staż pracy (gdy w okresie podwyższenia i zrównywania wieku emerytalnego minimalny staż pracy miał docelowo wynosić 25 lat dla obu płci). 


\section{System emerytalny wobec zasady solidarności społecznej}

Wydaje się, że system emerytalny z zasady winien służyć wzmacnianiu więzi społecznych. Beneficjenci oczekują od państwowego systemu emerytalnego, że będzie on ponadto służył budowie wzajemnego zaufania państwa i interesariuszy, opierając się na zasadzie solidaryzmu. Tymczasem w kontynentalnym modelu emerytalnym (Kalina-Prasznic 2012, s. 29) nad zasadą solidaryzmu dominuje zasada ekwiwalentności. Wynika ona z przekonania, że społeczne ubezpieczenie emerytalne stanowi odzwierciedlenie przezorności oraz solidarności osób zagrożonych ryzykiem starości. Solidarność dotyczy przede wszystkim wspólnoty ryzyka w procesie gromadzenia funduszy (składki emerytalne) i ich podziale (wypłata świadczeń). Jednostkową, zindywidualizowaną ekwiwalentność odzwierciedla (Kalina-Prasznic 2013, s. 226) powiązanie poziomu przyszłych świadczeń z wysokością składek.

Z prognoz demograficznych wynika, że do 2050 roku liczba osób pracujących zmniejszy się. Ponad połowę mieszkańców stanowić będą osoby w wieku nieprodukcyjnym. Szacuje się, że w najbliższych dekadach zmieni się zarówno wskaźnik obciążenia demograficznego, jak i liczba urodzeń (Popek, Wanat 2016). Relacja osób $\mathrm{w}$ wieku nieprodukcyjnym do osób $\mathrm{w}$ wieku produkcyjnym ulegnie zmianie, wywołując zarówno skutki społeczno-demograficzne, jak i ekonomiczne.

Procesy demograficzne, wywierając wpływ na relację pomiędzy liczbą emerytów a ogółem ubezpieczonych, kształtują zarazem sytuację finansową Funduszu Ubezpieczeń Społecznych (FUS). Stabilność Funduszu opiera się na zapewnieniu określonych kwot, wpłacanych do systemu składkowego - z jednej strony, a także sumie (czyli wysokości) wypłacanych świadczeń $-\mathrm{z}$ drugiej. W tym kontekście należy rozpatrywać również problem redystrybucji dochodów. Redystrybucja ubezpieczeniowa (której źródło stanowią składki ubezpieczeniowe) opiera się na finansowym kontrakcie pomiędzy pokoleniem pracujących (ubezpieczeni) a pokoleniem seniorów (emeryci). Poziom (i kwota) składek na fundusz ubezpieczeniowy zależy od ryzyka (jest ono szacowane), przyjmując równocześnie, że ewentualne straty kompensowane są z funduszu ubezpieczeń (Kucharczyk-Rok, Rawski, Żołna 2013, s. 158).

Uwzględnienia wymaga również relacja liczby osób ubezpieczonych do łącznej liczby osób pobierających emeryturę, a także jej zmienność w czasie. W latach 2020-2060 prognozowana jest $\mathrm{w}$ tym zakresie zmiana na niekorzyść pracujących (Kalina-Prasznic 2013). ZUS szacuje, że w roku 2040 potencjalnego emeryta będzie „utrzymywać” jedynie dwóch pracujących, zamiast czterech, jak ma to miejsce obecnie (Karcewicz 2017). Może to w efekcie oznaczać, że finansowanie jednej emerytury będzie wymagało udziału składkowego wnoszonego przez mniej niż dwóch ubezpieczonych. Prognozowane relacje pomiędzy ilością osób w wieku przedprodukcyjnym, produkcyjnym oraz poprodukcyjnym $\mathrm{w}$ Polsce $\mathrm{w}$ latach 2020-2050 przedstawiono na Rysunku 1. Natomiast potencjalne zmiany relacji liczby ubezpieczonych i emerytów w okresie 2020-2060 według prognozy ZUS przedstawiono na Rysunku 2. 


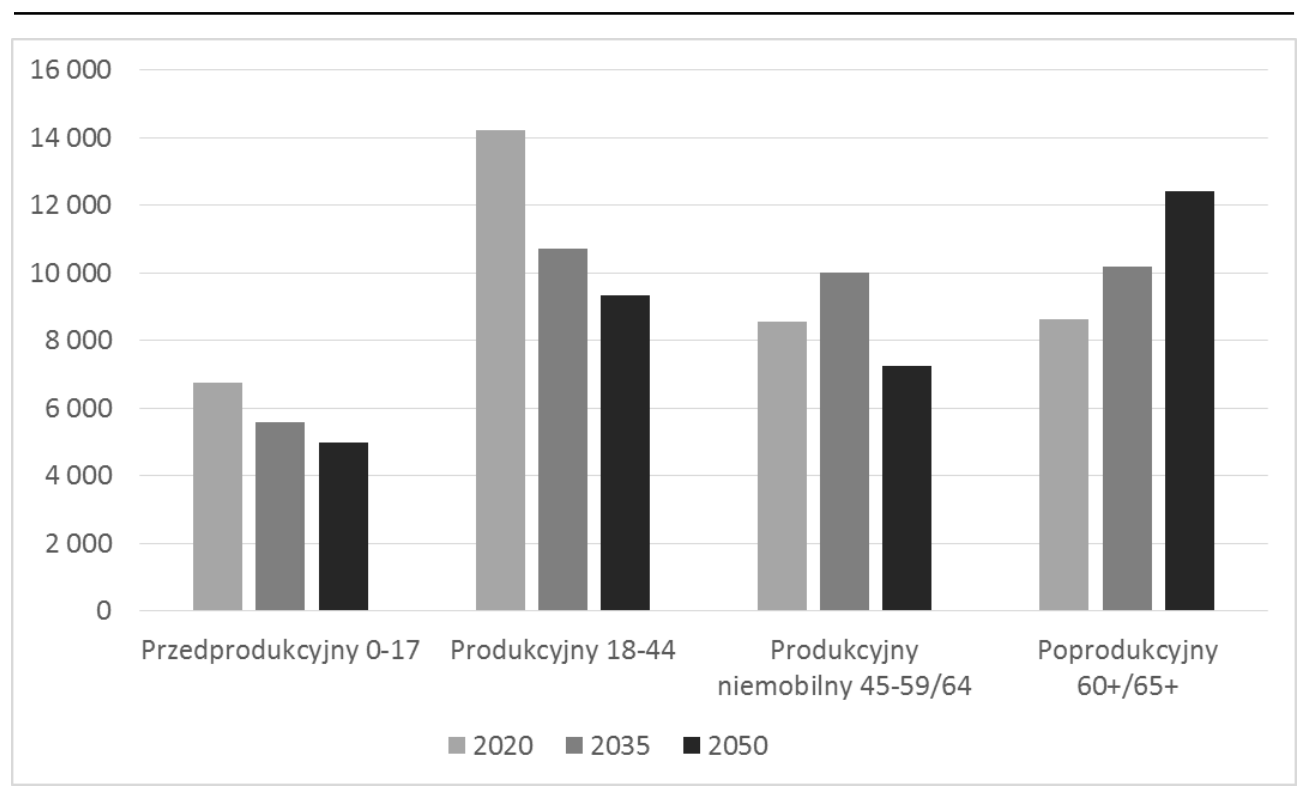

Rysunek 1. Prognozowane relacje pomiędzy ilością osób w wieku przedprodukcyjnym, produkcyjnym oraz poprodukcyjnym w Polsce w latach 2020-2050 [dane liczbowe podano w tys. osób]

Źródło: Opracowanie własne na podstawie (Karcewicz 2017; ZUS 2013)

Konsekwencją tej niekorzystnej relacji będzie prawdopodobny wzrost udziału składek na ubezpieczenie społeczne w kosztach ogólnych wynagrodzeń za pracę (Golinowska, Boni (red.) 2006, s. 142). Tymczasem wysokość emerytur pozostaje w zależności od wielkości PKB i jego międzypokoleniowej redystrybucji (Chybalski 2013, s. 13). Ewentualny wzrost wysokości emerytur implikuje równoczesny wzrost udziału emerytów w podziale PKB, działając na niekorzyść innych grup pokoleniowych, w tym osób zawodowo aktywnych oraz ich dzieci.

Gdyby realnie opierać się na idei solidarności społecznej, państwo powinno promować takie rozwiązania, które potencjalną kwotę przyszłej emerytury wywodzą bezpośrednio z wysokości zgromadzonego kapitału. Zasada ta do niedawna nie obejmowała wszystkich grup społecznych włączonych do powszechnego systemu emerytalnego. Katalog osób uprawnionych był szeroki, ale proces „wygaszania” prawa do świadczeń oddalano w czasie. Wydaje się, że stosowanie preferencji emerytalnych dla wybranych grup zawodowych, które nie byłyby zobowiązane do świadczenia pracy aż do osiągnięcia powszechnego wieku emerytalnego, nie ma uzasadnienia racjonalnego i ekonomicznego, pozostając w sprzeczności z zasadą sprawiedliwości społecznej. Przepisy prawa odnoszą te preferencje m.in. do grup zawodowych: górników, kolejarzy, nauczycieli, a ponadto osób zatrudnionych w tak zwanych szczególnych warunkach lub w szczególnym charakterze (por.: Ustawa z dnia 17 grudnia 1998 r. ...). 


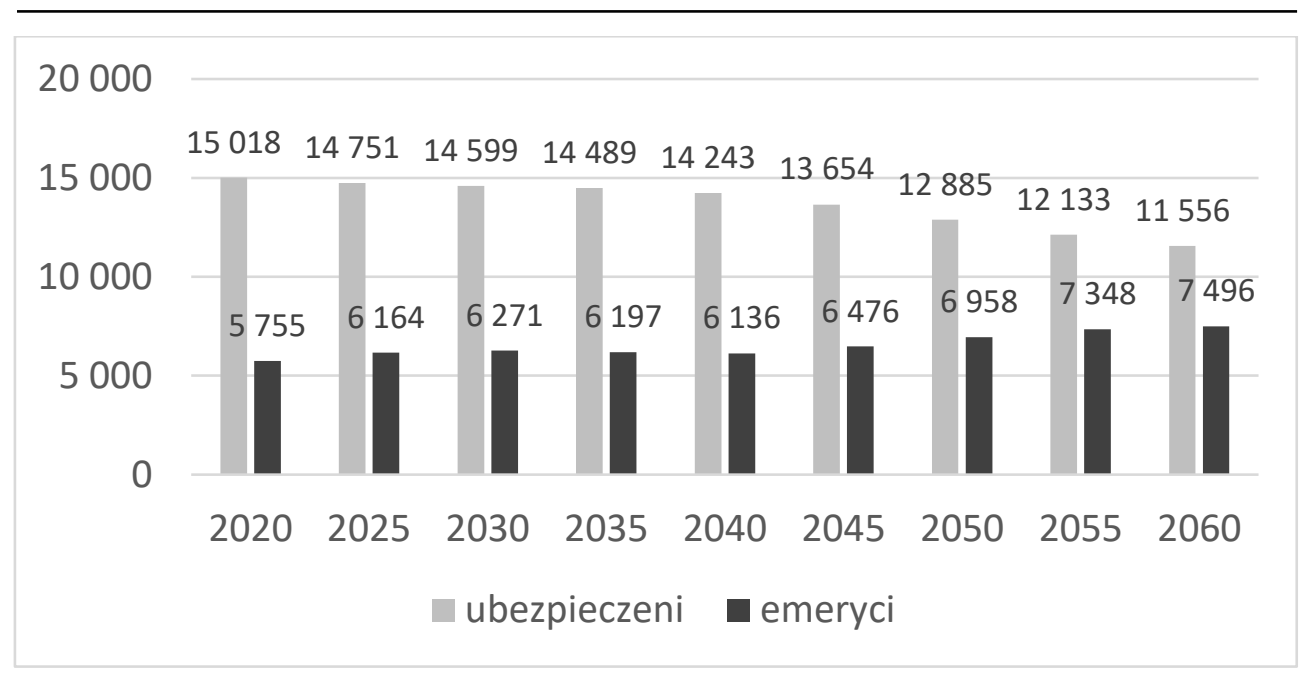

Rysunek 2. Potencjalne zmiany relacji liczby ubezpieczonych i emerytów w okresie 2020-2060 według prognozy ZUS [dane liczbowe podano w tys. osób]

Źródło: Opracowanie własne na podstawie (Karcewicz 2017; ZUS 2013)

Warto zauważyć, że z finansowego punktu widzenia wcześniejsze emerytury stanowią obciążenie zarówno dla obecnych ubezpieczonych, jak również dla przyszłych emerytów. Trudno także zlekceważyć sytuację, w której osoby korzystające z przywilejów wcześniejszej emerytury otrzymują ją, zachowując równocześnie pełną zdolność do pracy i posiadając wysokie do niej kompetencje zawodowe. Dylemat ten nie wydaje się być możliwym do rozstrzygnięcia ani na korzyść państwa czy gospodarki, ani też na rzecz beneficjentów systemu emerytalnego. Implikuje on konieczność stałych dopłat budżetowych do ubezpieczeń emerytalnych. Konsekwencją rezygnacji osób wykształconych, praktyków z wieloletnim doświadczeniem zawodowym, może być poważna nierównowaga na rynku pracy. Ponadto perspektywa eliminacji relatywnie młodych emerytów z ich dotychczasowych przestrzeni aktywności może prowadzić do poczucia wyalienowania, osłabienia relacji międzyludzkich i samotności, następnie do ograniczenia możliwości realizacji potrzeb, w tym także materialnych, zaś w konsekwencji nawet do wykluczenia społecznego.

Konieczna wydaje się więc identyfikacja czynników, które wywierają wpływ na osłabienie systemu zabezpieczenia emerytalnego. Zdaniem U. Kaliny-Prasznic (Kalina-Prasznic 2013, s. 233-234) dotychczasowy system emerytalny przebudowano według zasad neoliberalnych. W modelu tym eksponuje się prywatyzację oraz indywidualizację ryzyka starości, przy równoczesnym odrzuceniu idei solidarnego gromadzenia i redystrybucji środków. Na problem osłabienia więzi społecznych wskazuje M. Żukowski (Żukowski 2006, s. 89), zauważając, że powiązanie wysokości emerytury z wkładem własnym ubezpieczonego stopniowo eliminuje solidarność obywatelską. Indywidualne konta emerytalne (IKE) ograni- 
czyły wzajemność ubezpieczeniową. Częściowe zastąpienie finansowania repartycyjnego poprzez finansowanie kapitałowe osłabiło solidaryzm międzypokoleniowy (Żukowski 2006).

\section{Spór o podstawowy wiek emerytalny}

Ustawowy wiek nabycia prawa do emerytury stanowi punkt wyjścia każdego systemu emerytalnego, a niekiedy najważniejszy parametr tego systemu (Żukowski 2012, s. 5). W powszechnym systemie ubezpieczeń społecznych wiek, wyznaczający niezdolność do pracy, stanowi ryzyko chronione każdego ubezpieczonego. W literaturze przedmiotu dominuje pogląd, że zarówno w systemie zdefiniowanego świadczenia, jak i systemie zdefiniowanej składki wiek emerytalny wyznacza moment rozpoczęcia konsumpcji emerytalnej (Żukowski, Szumlicz 2004, s. 17). Zapisy Konwencji Międzynarodowej Organizacji Pracy (nr 102) określają, że granica wieku przejścia na emeryturę powinna być adekwatna zarówno do warunków funkcjonowania systemu emerytalnego, jak i do potencjalnej zdolności do pracy osób starszych. Wiek przejścia na emeryturę powinien więc odpowiadać zarówno sytuacji zdrowotnej, jak i rzeczywistej zdolności do pracy uczestników systemu emerytalnego.

Warto przywołać również pogląd polemiczny, który podnosi, że emerytury wymyślono w celu finansowania starców, którzy ukończyli 70 lat życia. Faktyczny wiek przejścia na emeryturę jest obecnie znacznie niższy. Prawo do świadczeń nabywają osoby w wieku około 60 lat, który nie jest wiekiem starczym. Z kolei środki przeznaczone na finansowanie prawdziwej starości 80-latków okazują się niewystarczające (Góra 2011). Szczególne znaczenie kryterium wieku emerytalnego podkreśla J.E. Stiglitz (Stiglitz 2004, s. 12), wskazując na obligatoryjność tego czynnika w każdym systemie ubezpieczeń społecznych. Autor ten uważa, że wiek emerytalny należy dostosować do zmieniającej się rzeczywistości. Wiek emerytów powinien równoważyć finanse państwa, które z kolei winno gwarantować bezpieczeństwo finansowe przyszłym emerytom. Gwarancja ta powinna więc zapewniać godziwe środki do życia osobom, które ze względu na wiek, liczbę przepracowanych lat pracy oraz kwotę zgromadzonego kapitału finansowego zdecydują o rezygnacji z dalszej pracy zawodowej.

Równocześnie, jak podaje D.J. Sanders (Sanders 2008, s. 57), większość wyborów dokonywanych przez człowieka powinna zmierzać do możliwie najdłuższej aktywności zawodowej. Autor ten podkreśla znaczenie samodzielnego zarabiania na życie, ale także - przede wszystkim - świadomość społecznej użyteczności człowieka, czyli poczucia, że „robimy coś ważnego, na co mamy bezpośredni wpływ".

Rzeczywisty wiek odejścia z rynku pracy w relacji do oficjalnego wieku emerytalnego dla obu płci stanowi czynnik istotny, a zarazem zróżnicowany w wielu krajach i ich systemach emerytalnych. Warto podkreślić, że ustawowy, oficjalny wiek emerytalny jest $\mathrm{w}$ przeważającej większości przypadków niższy niż rzeczywisty wiek przejścia na emeryturę (Uścińska 2012, s. 23-38). W praktyce polskiej relatywnie niski wiek przechodzenia na emeryturę uznawano uprzednio za zasadę. 
Dominowała praktyka posługiwania się wczesnymi emeryturami, stanowiąc swoisty instrument kształtowania podaży na rynku pracy. Od 1 stycznia 2009 roku krąg osób uprawnionych do wcześniejszej emerytury został ograniczony. Zachowano preferencje dla tych grup zawodowych, które skatalogowano ustawowo. Do końca 2012 roku obowiązywał w polskim ustawodawstwie zróżnicowany wiek emerytalny dla kobiet i mężczyzn (odpowiednio 60 i 65 lat). Od 1 stycznia 2013 roku wiek emerytalny ujednolicono. Kryterium to ustanowiono (docelowo) na poziomie 67 lat dla obu płci (w odniesieniu do daty urodzenia ubezpieczonego). Proces zmian rozłożono w czasie, a stopniowe podwyższanie wieku odbywało się w okresach kwartalnych (o jeden miesiąc). Zakładano, że osiągnięcie poziomu docelowego nastąpi dla mężczyzn w roku 2020, a dla kobiet odpowiednio w roku 2040.

Podwyższenie i zrównanie wieku emerytalnego dla obu płci nie uzyskało akceptacji społecznej. Z perspektywy instytucjonalnej miało przyczynić się do zmniejszenia wydatków budżetowych państwa (Funduszu Ubezpieczeń Społecznych). Dłuższa praca ubezpieczonego miała zarazem zapewnić wyższą kwotę emerytury, a tym samym wyższą stopę zastąpienia (Widerska 2013, s. 377). Proces zmian stał się wyzwaniem dla kobiet, wobec podnoszonego niekiedy zarzutu, jakoby to kobiety były głównymi beneficjentkami systemu ubezpieczeń społecznych (częściej korzystając z urlopów wychowawczych, krócej oszczędzając i dłużej pobierając emeryturę). Prawdopodobnie w sporze tym zapomniano o szczególnej roli kobiet $\mathrm{w}$ zabezpieczeniu funkcjonowania rodziny i bezpieczeństwa międzypokoleniowego, które to elementy są trudne do skwantyfikowania (albo wręcz niemierzalne), stąd też bywają często pomijane bądź eliminowane $\mathrm{z}$ analiz (por.: Klimkiewicz 2017).

Wyznaczenie racjonalnego i możliwie optymalnego wieku emerytalnego w systemie ubezpieczeń społecznych stanowi ważny etap jego kształtowania i restrukturyzacji. Przy słabości argumentacji ekonomicznej, wątpliwościach co do społecznej akceptacji oraz rosnącym obciążeniu finansów państwa kosztami obsługi wypłat długoterminowych świadczeń proces ten jest poważnym wyzwaniem (por.: Szczepański 2016). Konieczna wydaje się również weryfikacja hipotezy twierdzącej, że podwyższenie wieku emerytalnego wpłynie negatywnie na sytuację demograficzną Polski. Ponadto za niezbędne uznać należy zarządzanie kosztami, bezpośrednio związanymi z koniecznością utrzymania struktury systemu emerytalnego wraz z jego drugim filarem (Oręziak, Rosati (red.) 2013, s. 267).

\section{System emerytalny wobec aktywności zawodowej seniorów i dalszego trwania życia}

Chociaż starość jest procesem naturalnym właściwym każdemu człowiekowi i nauki społeczne wyznaczają poszczególne etapy starości, trudno jednoznacznie określić, od którego momentu zaczyna się okres niezdolności do pracy ze względu na wiek. System emerytalny powinna cechować elastyczność, zarówno w zakresie wyznaczania optymalnego wieku emerytalnego, jak i momentu zakończenia zatrudnienia. Dalsze trwanie życia należy do istotnych uwarunkowań redystrybucji międzypokoleniowej. Jednakże rzeczywista długość poszczególnych etapów życia, 
na których opiera się system emerytalny, zmienia się w czasie. Proces zmian powoduje, że wydłużają się poszczególne jego fazy: młodość, dojrzałość, starość. Sprawia, że starość, której pojęcie bywa współcześnie nieostre, również dzieli się na kilka dających się wyodrębnić etapów (Latos-Miłkowska 2014, s. 3). Umowny model klasyfikacyjny etapów starości przedstawiono w Tabeli 1 .

Tabela 1. Model i klasyfikacja etapów starości (w odniesieniu do grup wiekowych)

\begin{tabular}{|c|c|c|}
\hline $\begin{array}{c}\text { Wiek } \\
\text { (w latach) }\end{array}$ & $\begin{array}{c}\text { Etapy } \\
\text { starości }\end{array}$ & $\begin{array}{c}\text { Klasyfikacja } \\
\text { (wiek) starości }\end{array}$ \\
\hline $60-74$ & młoda starość & I \\
$75-89$ & dojrzała starość & II \\
$90 \mathrm{i}$ więcej & długowieczność & III \\
\hline
\end{tabular}

Źródło: Opracowanie własne na podstawie (Latos-Miłkowska 2014)

W 2017 roku w systemie ubezpieczeń społecznych dokonano kolejnych zmian. Począwszy od 1 października 2017 roku, podstawowy wiek emerytalny dla obu płci ponownie zróżnicowano. Wiek ten określono na poziomie 60 lat dla kobiet i 65 lat dla mężczyzn. Tę grupę osób, biorąc pod uwagę klasyfikację etapów starości, określa się mianem ludzi starszych (tzw. młoda starość). Wobec kryzysu demograficznego, zwanego niekiedy katastrofą demograficzną, nie powinno się arbitralnie eliminować z rynku pracy przyszłych, potencjalnych emerytów. W tym kontekście ewentualna możliwość dalszego zatrudnienia osób w okresie młodej starości, chcących pracować i zdolnych do pracy ze względu na stan zdrowia, zasługuje na wsparcie państwa i uwzględnienie w strategiach rozwoju (Popek, Wanat 2016).

W Polsce wskaźnik zatrudnienia osób w wieku 55-64 lat wynosi 41\%, natomiast $\mathrm{w}$ krajach OECD średni odsetek zatrudnienia osób w tym wieku stanowi 55\% (OECD 2015). Sytuacja ta występuje nawet mimo systemu ulg, które wiążą się z zatrudnieniem pracowników w wieku powyżej 50 lat. Przedsiębiorstwa zatrudniające kobiety powyżej 55 lat i mężczyzn powyżej 60 lat zwolnione są z opłat na rzecz Funduszu Pracy i Funduszu Gwarantowanych Świadczeń Pracowniczych. Ponadto w przypadku absencji chorobowej tych osób pracodawca ponosi koszty tej absencji jedynie przez 14 dni w roku. Okazuje się jednak, że preferencje te są dla pracodawców mało atrakcyjne. Konieczne zatem wydaje się uaktywnienie roli państwa $\mathrm{w}$ zakresie instytucjonalnych narzędzi wsparcia polityki zatrudnienia, umożliwiające tworzenie nowych i wydajnych stanowisk pracy.

Zdaniem Jarmołowicza (Jarmołowicz, Knapińska 2008 s. 100) jedynie kompleksowe oddziaływanie państwa na rozwój gospodarki umożliwiać może wysokie i racjonalne zatrudnienie. Uwzględniając potencjalną aktywność zawodową seniorów, przynajmniej cześć stanowisk pracy powinna zostać dostosowana do wieku oraz możliwości osób starszych. Konieczne wydaje się więc wprowadzenie systemu instytucjonalnych zachęt dla pracodawców (np. preferencji czy ulg podatkowych) wobec pracodawców, a równolegle wzmocnienie profilaktyki i opieki zdro- 
wotnej pracowników w okresie tzw. młodej starości. Nie jest to jednak możliwe bez dodatkowego obciążenia budżetu państwa.

Jak wskazuje Marody (Marody 2012, s. 63-76), etos pracy Polaków podlegał w ostatnich dekadach silnym przemianom. Pracę, obok rodziny, uznaje się za kluczowe w hierarchii wartości i oczekiwań społecznych Polaków. Zmienność postaw społeczeństwa polskiego wobec pracy stanowi zarazem odzwierciedlenie nierównowagi na tym rynku. Od pracownika oczekuje się solidnego wykonania obowiązków, kreatywności i elastyczności, a zarazem dyspozycyjności, czyli nienormowanego czasu pracy.

Tabela 2. Zróżnicowanie kwot ograniczenia rocznego wynagrodzenia oraz kwot składki emerytalnej w latach 1999-2016

\begin{tabular}{|c|c|c|}
\hline Rok & $\begin{array}{c}\text { Kwota } \\
\text { wynagrodzenia } \\
\text { (PLN) }\end{array}$ & $\begin{array}{c}\text { Skladka } \\
\text { emerytalna } \\
\text { (PLN) }\end{array}$ \\
\hline 1999 & 50375,22 & 9833,24 \\
2000 & 54780,00 & 10693,06 \\
2001 & 62940,00 & 12285,89 \\
2002 & 64620,00 & 12613,82 \\
2003 & 65850,00 & 12853,92 \\
2004 & 68700,00 & 13410,24 \\
2005 & 72690,00 & 14189,09 \\
2006 & 73560,00 & 14358,91 \\
2007 & 78480,00 & 15319,30 \\
2008 & 85290,00 & 16648,61 \\
2009 & 95790,00 & 18698,21 \\
2010 & 94380,00 & 18422,98 \\
2011 & 100770,00 & 19670,30 \\
2012 & 105780,00 & 20648,26 \\
2013 & 111390,00 & 21743,33 \\
2014 & 112380,00 & 21936,58 \\
2015 & 118770,00 & 23170,24 \\
2016 & 121650,00 & 23746,08 \\
2017 & 127890,00 & 24964,13 \\
\hline
\end{tabular}

Źródło: Opracowanie własne na podstawie (Karcewicz 2017)

Tymczasem, jak zauważa G.W. Kołodko (Kołodko 2013, s. 402), za ekonomiczny i społeczny nonsens należy uznać stan, w którym jedni pracownicy podejmują ponadwymiarową aktywność zawodową, inni zaś pozostają bez pracy. Jedni zarabiają dostatecznie dużo, inni zaś pozbawieni są minimalnych dochodów, które pozwalałyby na zaspokojenie potrzeb podstawowych. Kołodko wskazuje, że $\mathrm{w}$ tak zidentyfikowanej sytuacji pracą należy się podzielić. System emerytalny 
powinien uwzględnić rolę osób, które chcą i mogą nadal pracować, pozostając aktywnymi uczestnikami rynku pracy.

W obecnym systemie ubezpieczeń wysokość emerytury uzależniono bezpośrednio od wysokości składek zgromadzonych na koncie przyszłego beneficjenta. Im wyższe wynagrodzenie ubezpieczonego, tym wyższa kwota świadczenia przyszłego emeryta. Warto zauważyć, że dłuższy okres pracy nie musi w sposób istotny wpłynąć na wysokość emerytury. Natomiast dłuższy okres pracy (ubezpieczenia) połączony z relatywnie wysoką kwotą wynagrodzenia (a zarazem wysokością składek) może w istotny sposób wpłynąć na zwiększenie kwoty przyszłej emerytury.

Od roku 1999 maksymalna kwota, od której odprowadzane są składki na ubezpieczenie emerytalne, została ograniczona do wysokości 30-krotności przeciętnego wynagrodzenia (Tabela 2). Jedynie ewentualne uwolnienie tej kwoty może spowodować, że na koncie ubezpieczonego zostanie zgromadzona wyższa kwota (suma) składek. Dla zobrazowania tej sytuacji poziom zróżnicowania kwot ograniczenia rocznego wynagrodzenia oraz kwot składki emerytalnej w latach 1999-2017 (w PLN) zestawiono w Tabeli 2.

Następnie zaprezentowano (Tabela 3) przykładową symulację wzrostu kwoty emerytury dla umownych beneficjentów systemu emerytalnego. Symulację przeprowadzono dla kobiety ( $\mathrm{K}$ w wieku 61 lat) i mężczyzny ( $\mathrm{M}$ w wieku 66 lat), dla których założono osiąganie odpowiednio minimalnego, przeciętnego i maksymalnego wynagrodzenia (przyjmując zarazem średnie dalsze trwanie życia wyrażone w miesiącach: dla $\mathrm{K}=252,0$ oraz $\mathrm{M}=209,2$ ).

$\mathrm{Z}$ analizy zestawionych danych można wnioskować, że im wyższa kwota wynagrodzenia przy relatywnie krótszym okresie średniego dalszego trwania życia, tym wyższa kwota przyrostu świadczenia emerytalnego.

Z kolei symulację zmian (potencjalnego wzrostu) kwot emerytury beneficjenta systemu emerytalnego (K-61, M-66) z tytułu osiągania wynagrodzenia w 2016 roku w kwotach: minimalnej, przeciętnej i maksymalnej, przedstawiono w Tabeli 3.

Tabela 3. Symulacja zmian (potencjalnego wzrostu) kwoty emerytury beneficjenta systemu emerytalnego (K-61, M-66) z tytułu osiągania wynagrodzenia w roku 2016 w kwotach: minimalnej, przeciętnej i maksymalnej

\begin{tabular}{|c|c|c|c|}
\hline \multirow{2}{*}{$\begin{array}{c}\text { Kwota } \\
\text { wynagrodzenia }\end{array}$} & Kwota skladek & \multicolumn{2}{|c|}{ Wzrost kwoty emerytury } \\
\cline { 3 - 4 } & emerytalnych & $\begin{array}{c}\mathbf{2 5 2 , 0} \\
\text { (miesięcy) }\end{array}$ & $\begin{array}{c}\mathbf{M} \\
\mathbf{2 0 9 , 2} \\
\text { (miesięcy) }\end{array}$ \\
\hline 22 200,00 (minimalna) & 4333,44 & 17,20 & 20,71 \\
48 566,52 (przeciętna) & 9480,18 & 37,62 & 45,32 \\
121650,00 (maksymalna) & 23746,08 & 94,98 & 113,51 \\
\hline
\end{tabular}

Źródło: Opracowanie własne 


\section{Obniżenie i zróżnicowanie powszechnego wieku emerytalnego dla ko- biet i mężczyzn oraz ich konsekwencje}

Chociaż poglądy prezentowane w literaturze nie dają jednoznacznej rekomendacji, to dotychczasowe doświadczenia zdają się wskazywać, że obniżenie i zróżnicowanie podstawowego wieku emerytalnego dla kobiet (60 lat życia) i mężczyzn (65 lat życia) ma relatywnie większą szansę na uzyskanie społecznej akceptacji (Klimkiewicz 2017). Sytuacja ta rodzi określone konsekwencje zarówno dla państwa, jak i dla beneficjentów systemu ubezpieczeń społecznych (Szczepański 2016; Malec, Tyrowicz 2017).

Zestawienie potencjalnych oczekiwań i zagrożeń, stanowiących konsekwencję zmian w systemie ubezpieczeń społecznych w Polsce, przedstawiono w Tabeli 4.

Tabela 4. Potencjalne szanse i zagrożenia jako konsekwencja obniżenia powszechnego wieku emerytalnego $\mathrm{z}$ perspektywy instytucjonalnej (państwo) i indywidualnej (beneficjenci systemu emerytalnego)

\begin{tabular}{|c|c|c|}
\hline $\begin{array}{c}\text { Szanse } \\
\text { i } \\
\text { zagrożenia }\end{array}$ & $\begin{array}{c}\text { Perspektywa instytucjonalna } \\
\text { (państwo) }\end{array}$ & $\begin{array}{l}\text { Perspektywa indywidualna } \\
\text { (beneficjenci) }\end{array}$ \\
\hline Szanse & $\begin{array}{l}\text { - akceptacja społeczna, } \\
\text { - wzrost zaufania do systemu } \\
\text { emerytalnego, } \\
\text { - uzależnienie emerytury od własnego } \\
\text { wkładu, } \\
\text { - zwiększzenie wydolności finansowej } \\
\text { funduszu ubezpieczeń społecznych } \\
\text { FUS, } \\
\text { - większe wpływy składek do FUS, } \\
\text { - ograniczenie dotacji budżetu } \\
\text { państwa do FUS, } \\
\text { - wzrost gospodarczy, } \\
\text { - równoważenie finansów państwa, } \\
\text { - tworzenie nowych miejsc pracy, } \\
\text { - zwiększenie aktywności zawodowej } \\
\text { Polaków, } \\
\text { - stopniowe ,wygaszanie” aktywnych } \\
\text { pracowników, elastyczność } \\
\text { ograniczania aktywności } \\
\text { zawodowej, } \\
\text { - likwidacja, a przynajmniej znaczące } \\
\text { ograniczenie szarej strefy na rynku } \\
\text { pracy. }\end{array}$ & $\begin{array}{l}\text { - fakultatywność wyboru wieku } \\
\text { przejścia na emeryturę, } \\
\text { - sprawiedliwy system } \\
\text { emerytalny, } \\
\text { - stabilność systemu } \\
\text { emerytalnego, } \\
\text { - wiek emerytalny powiązany } \\
\text { z długością życia, } \\
\text { - realna średnia długość trwania } \\
\text { życia, } \\
\text { - niższe składki emerytalne oraz } \\
\text { składki rentowe, } \\
\text { - działania na rzecz trwania } \\
\text { w zdrowiu (profilaktyka } \\
\text { i ochrona zdrowia), } \\
\text { - profesjonalne zarządzanie } \\
\text { wiekiem, } \\
\text { - korzystne zasady łączenia } \\
\text { emerytury z pracą, } \\
\text { - perspektywa dłuższego } \\
\text { odpoczynku na emeryturze, } \\
\text { - jawność finansów systemu } \\
\text { emerytalnego. }\end{array}$ \\
\hline Zagroż & $\begin{array}{l}\text { - pauperyzacja emerytów, } \\
\text { - dopłaty do opieki społecznej, } \\
\text { - wzrost zachorowalności. }\end{array}$ & $\begin{array}{l}\text { - niższa kwota zastápienia, } \\
\text { - alienacja emerytów, } \\
\text { - wykluczenie społeczne. }\end{array}$ \\
\hline
\end{tabular}

Źródło: Opracowanie własne 
Jak zauważył J.S. Orczyk (Orczyk 2008, s. 110), kwestia skali i form interwencji państwa w system zabezpieczenia emerytalnego zawsze budziła liczne kontrowersje. Społeczeństwo oczekuje bowiem realizacji jednego z podstawowych praw człowieka, jakim jest prawo do zabezpieczenia minimum jego egzystencji, a państwo winno być jego gwarantem (Golinowska, Boni 2006, s. 169). Konsekwencją wieloletniej pracy powinna okazać się nie tyle jakaś teoretyczna gwarancja zapewnienia minimum egzystencji emeryta, ale raczej takiej emerytury, która stanowi o godności człowieka, a nie przesądza o jego społecznym, choćby stopniowym, wykluczeniu. Trudno zarazem dziwić się, jak zauważa M. Wanat, poszukiwaniom alternatywnych form zabezpieczenia emerytalnego, w tym rent hipotecznych czy instrumentów kredytowych tzw. „odwróconej hipoteki” (reverse mortgage), których rozwój w warunkach polskich może wywrzeć znaczący wpływ nie tylko na sytuację ekonomiczną, ale przede wszystkim na sytuację społeczną emerytów i ich rodzin (Wanat 2015, s. 111-124). W takiej perspektywie sytuacja równoczesnego funkcjonowania $\mathrm{w}$ tym samym, powszechnym systemie ubezpieczeń, zarówno bogatych emerytów w okresie tzw. młodej starości oraz wieloletnich pracowników, żyjących poniżej minimum kosztów utrzymania, z emerytury, która nie jest w stanie konkurować z jałmużną, jawi się jako zjawisko patologiczne.

Permanentna ewaluacja efektywności powszechnego systemu emerytalnego oraz jawność finansów operatora państwowych ubezpieczeń wydaje się koniecznością. Ponadto badanie społecznej użyteczności systemu ubezpieczeń oraz podjęcie wysiłku modyfikacji tego systemu, gdy wskazują na to uwarunkowania ekonomiczne i społeczne, nie może być jedynie postulatem teoretycznym. Jawność systemu, jego monitoring (benchmarking) i ewaluacja wymagają przede wszystkim dialogu społecznego oraz nowoczesnego, skutecznego przywództwa (por.: Potkański, Wanat, Chudobiecki 2011). Korzystając z dotychczasowych doświadczeń jednostek samorządu terytorialnego, można zarazem sądzić, że nie jest możliwe podejmowanie wrażliwych społecznie wyzwań, dotyczących kluczowych zagadnień polskiej polityki rozwoju, bez międzysektorowej i międzysamorządowej współpracy (Potkański (red.) 2016; Potkański, Wanat 2017, s. 235-245). Pewną pomocą w procesie wdrażania koniecznych zmian mogą okazać się wypracowane w sektorze samorządowym dobre praktyki zarządzania oraz modele współpracy (Wanat 2016, s. 141-163), oparte na sprawdzonych w praktyce instytucjonalnych narzędziach wsparcia.

\section{Podsumowanie}

Spór o wiek emerytów w polskim powszechnym systemie emerytalnym wynika z priorytetów organizacji i zarządzania polityką społeczną państwa. Z uwagi na wrażliwość problematyki i rozbieżność interesów wszystkich zainteresowanych podmiotów pozostanie on zapewne sporem permanentnym. W podobnym kontekście oceniana będzie solidarność, ekwiwalentność i sprawiedliwość tego systemu, zależnie od przyłożonej doń miary. Celem wysiłków badawczych powinno więc być wyznaczenie przynajmniej punktu odniesienia, miary minimalnej, na której 
można będzie podjąć próbę określenia akceptowalnych społecznie definicji solidarności, ekwiwalentności oraz sprawiedliwości powszechnego systemu emerytalnego w Polsce. Wydaje się, że zadanie sformułowania takich definicji w aktualnych warunkach społeczno-ekonomicznych ciągle pozostaje niezrealizowanym wyzwaniem.

Owszem, przeprowadzane w przestrzeni nauk ekonomicznych badania wykazują, że jakość zabezpieczenia emerytalnego Polaków zależy nie tylko od sytuacji finansów publicznych i pozycji ekonomicznej państwa, ale wynika z priorytetów polityki społecznej, której podmiotem i beneficjentem powinien być i pozostać człowiek. Proces reformy systemu emerytalnego powinien więc być ukierunkowany antropocentrycznie (i społecznie), a weryfikowany ekonomicznie. W systemie zdefiniowanej składki emerytalnej głównym jej celem jest uzależnienie wysokości emerytury od wkładu własnego. Spór o podstawowy wiek emerytalny będzie więc z uzasadnionych przyczyn stałym tematem badań nauk o zarządzaniu, zarówno z perspektywy ekonomicznej, społecznej, jak i politycznej. Do priorytetów badawczych zaliczyć należy zarówno kwestię ujednolicenia wieku przejścia na emeryturę, jak również problem ograniczenia (likwidacji) szczególnych przywilejów emerytalnych różnych grup zawodowych, których uzasadnienie społeczne, etyczne i ekonomiczne wydaje się wątpliwe.

Prawo do zabezpieczenia emerytalnego i obsługa systemu emerytalnego powinny opierać się na stabilności finansów publicznych państwa. To instytucja państwa winna chronić i zapewniać prawo ubezpieczonego, legitymującego się wieloletnim stażem pracy i zgromadzonym kapitałem, do uzyskania godnego dochodu na starość. Wydaje się, że oparcie rozwiązań systemowych na zasadzie wolności wyboru, zgodnie $\mathrm{z}$ którą każdy ubezpieczony osiągający podstawowy wiek emerytalny i legitymujący się określoną liczbą lat pracy może zdecydować, czy skorzystać z emerytury, czy też pozostać aktywnym uczestnikiem rynku pracy. $\mathrm{W}$ tak zarysowanym modelu to nie wiek emerytalny stanowić będzie najważniejszy element (fundament) powszechnego systemu emerytalnego, ale jego integralność. Miarą integralności powinna zaś być społeczna i ekonomiczna ekwiwalentność emerytur, odzwierciedlająca rzeczywiste odniesienie do zasad sprawiedliwości społecznej i solidarności międzypokoleniowej.

\section{Literatura}

1. Chybalski F. (2013), Dobrowolność przynależności do OFE a dywersyfikacja ryzyka w systemie emerytalnym w Polsce, [w:] Chybalski F., Marcinkiewicz E. (red.), Współczesne zabezpieczenie emerytalne. Wybrane aspekty ekonomiczne, finansowe i demograficzne, Wydawnictwo Politechniki Łódzkiej, Łódź, s. 11-22.

2. Golinowska S., Boni M. (red.) (2006), Nowe dylematy polityki spolecznej, Centrum Analiz Społeczno-Ekonomicznych, Warszawa.

3. Góra M. (2011), Jak zapewnić godziwe emerytury?, [w:] Forum Debaty Publicznej. „Solidarne państwo, bezpieczna rodzina”: Jak zapewnić godziwe dochody na starość dla przyszłych pokoleń, Warszawa, 18 maja 2011, http://docplayer.pl/4778500-Solidarnespoleczenstwo-bezpieczna-rodzina-jak-zapewnic-godziwe-dochody-na-starosc-dlaprzyszlych-pokolen-18-maja-2011-roku.html (dostęp: 02.10.2017), s. 61-66. 
4. GUS (2015), Aktywność ekonomiczna ludności Polski, Główny Urząd Statystyczny, Warszawa.

5. Jarmołowicz W., Knapińska M. (2008), Polityka zatrudnienia a polityka rynku pracy aspekty teoretyczne i realizacyjne, [w:] Jarmołowicz W. (red.), Przemiany na współczesnym rynku pracy, Wydawnictwo Forum Naukowe, Poznań, s. 71-100.

6. Kalina-Prasznic U. (2012), Społeczne zabezpieczenie emerytalne pracowników - między prawem a rynkiem, C.H. Beck, Warszawa.

7. Kalina-Prasznic U. (2013), Neoliberalny dogmatyzm a reformy spolecznego ubezpieczenia emerytalnego, [w:] Kalina-Prasznic U. (red.), Stare dogmaty - nowe wyzwania $w$ prawie i ekonomii, Wolters Kluwer, Warszawa, s. 223-236.

8. Karcewicz E. (2017), Struktura wysokości emerytur i rent wypłacanych przez ZUS po waloryzacji i podwyższeniu świadczeń najniższych w marcu 2017 roku, Zakład Ubezpieczeń Społecznych, Departament Statystyki i Prognoz Aktuarialnych, Warszawa.

9. Klimkiewicz A. (2017), Obniżenie wieku emerytalnego w Polsce. Implikacje dla kobiet w sferze rynku pracy, „Annales. Etyka w Życiu Gospodarczym”, t. 20, nr 2, luty 2017, s. 131-144. DOI: $10.18778 / 1899-2226.20 .2 .10$

10. Kołodko G.W. (2013), Dokąd zmierza świat. Ekonomia polityczna przyszłości, Prószyński Media, Warszawa.

11. Kołodziejczyk-Olczak I. (2014), Praktyki zarządzania międzypokoleniowego w obszarze rekrutacji i selekcji pracowników, „Zarządzanie Zasobami Ludzkimi”, nr 5, s. 29-42.

12. Kucharczyk-Rok Ł., Rawski O., Żołna O. (red.) (2013), Ubezpieczenie społeczne - dawniej i dziś. W 80-lecie uchwalenia ustawy o ubezpieczeniu społecznym, Zakład Ubezpieczeń Społecznych, Wrocław, s. 158.

13. Latos-Miłkowska M.Z. (2014), Prawo pracy wobec prognoz demograficznych, „Praca i Zabezpieczenie Społeczne", nr 12, s. 2-7.

14. Liwiński J., Sztanderska U. (2010), Wstępne standardy zarzadzania wiekiem w przedsiębiorstwach. Projekt „Z wiekiem na plus - szkolenia dla przedsiębiorstw”, Polska Agencja Rozwoju Przedsiębiorczości, Warszawa.

15. Lubrańska A. (2016), Polityka emerytalna jako element zarządzania wiekiem - teoria i praktyka, ,Polityka Społeczna”, nr 4, s. 14-21.

16. Malec M., Tyrowicz J. (2017), Niski wiek emerytalny, wysoka cena, [w:] Lewandowski P., Rutkowski J. (red.), Starzenie się ludności, rynek pracy $i$ finanse publiczne $w$ Polsce, Instytut Badań Strukturalnych, Przedstawicielstwo Komisji Europejskiej w Polsce, Warszawa, s. 29-34.

17. Marody M. (2012), Dynamika postaw wobec pracy, [w:] Jasińska-Kania A. (red.), Wartości i zmiany. Przemiany postaw Polaków w jednoczacej się Europie, Wydawnictwo Naukowe Scholar, Warszawa, s. 63-77.

18. OECD (2015), Pensions at a Glance 2015: OECD and G20 Indicators, OECD Publishing, Paris. DOI: 10.1787/pension_glance-2015-en

19. Olejnik I. (2016), Zabezpieczenie emerytalne. Modele i determinanty zachowań polskich gospodarstw domowych, Wydawnictwo Uniwersytetu Ekonomicznego w Poznaniu, Poznań.

20. Orczyk J.S. (2008), Polityka społeczna. Uwarunkowania i cele, Wydawnictwo Akademii Ekonomicznej w Poznaniu, Poznań.

21. Oręziak L., Rosati D.K. (red.) (2013), Kryzys finansów publicznych. Przyczyny, mechanizm, drogi wyjśsia, Oficyna Wydawnicza Uczelni Łazarskiego, Warszawa.

22. Popek M., Wanat L. (2016), Demographic Threats Facing Poland on the Basis of a Poll of Students of Poznań University of Economics and Business, „Zeszyty Naukowe Wyższej Szkoły Bankowej we Wrocławiu”, t. 16(3), s. 91-100.

23. Potkański T. (red.) (2016), Wspótpraca jednostek samorządu terytorialnego narzędziem wsparcia polskiej polityki rozwoju, Związek Miast Polskich, Poznań. 
24. Potkański T, Wanat L. (2017), Dylematy rozwoju miejskich obszarów funkcjonalnych zperspektywy partnerstw międzysamorzadowych, „Studia Komitetu Przestrzennego Zagospodarowania Kraju PAN”, nr 174, s. 235-245.

25. Potkański T., Wanat L., Chudobiecki J. (2011), Leadership in Time of Crisis or Crisis of Leadership? Implications for Regional Development, „Intercathedra”, No. 27(4), s. 45-52.

26. Rogozińska-Pawełczyk A. (2014), Zarządzanie kapitałem ludzkim w różnym wieku jako wyzwanie dla rynku pracy, [w:] Rogozińska-Pawełczyk A. (red.), Pokolenia na rynku pracy, Wydawnictwo Uniwersytetu Łódzkiego, Łódź, s. 17-37.

27. Samborski A. (2011), Determinanty zmian w systemach emerytalnych - ujęcie globalne, „Polityka Społeczna”, nr 2, s. 31-35.

28. Sanders D.J. (2008), Stworzeni, aby stużyć. Jak wptynać na wyniki firmy, pamiętajac o potrzebach pracowników, Wolters Kluwer, Kraków.

29. Stachowska S. (2012), Zarządzanie wiekiem w organizacji, „Zarządzanie Zasobami Ludzkimi", nr 3-4, s. 125-138.

30. Stiglitz J.E. (2004), Globalizacja, Wydawnictwo Naukowe PWN, Warszawa.

31. Szczepański M. (2016), Analiza i ocena proponowanych zmian ustawowego wieku emerytalnego w Polsce, „Finanse, Rynki Finansowe, Ubezpieczenia”, nr 1(79), s. 739-751. DOI: $10.18276 /$ frfu.2016.79-58

32. Urbaniak B. (2011), Zatrudnienie a instytucje rynku pracy $w$ warunkach starzejacych sie zasobów pracy - badania dla Polski, Wydawnictwo Uniwersytetu Łódzkiego, Łódź.

33. Ustawa z dnia 13 października 1998 r. o systemie ubezpieczeń społecznych (Dz.U. 1998 nr 137 poz. 887, z późn. zm.).

34. Ustawa $\mathrm{z}$ dnia 17 grudnia 1998 r. o emeryturach i rentach z Funduszu Ubezpieczeń Społecznych (Dz.U. 1998 nr 162 poz. 1118, z późn. zm.).

35. Uścińska G. (2012), Wiek emerytalny w krajach Unii Europejskiej - obowiazujace rozwiązania $i$ proponowane kierunki zmian, [w:] Żukowski M., Malak A. (red.), Wiek emerytalny, Polskie Stowarzyszenie Ubezpieczenia Społecznego, Kazimierz Dolny, s. 23-38.

36. Wanat M. (2015), Perspektywy rozwoju rynku reverse mortgage w Polsce, [w:] Bednarczyk T. (red.), Ubezpieczenia i bankowość z perspektywy młodego ekonomisty. Wybrane problemy, Wydawnictwo UMCS w Lublinie, Lublin, s. 111-124.

37. Wanat L. (2016), Dobre praktyki wspótpracy międzysamorządowej, [w:] Potkański T. (red.), Wspótpraca jednostek samorządu terytorialnego narzędziem wsparcia polskiej polityki rozwoju, Związek Miast Polskich, Poznań, s. 141-163.

38. Wanat L., Potkański T. (2010), Effective Leadership as One of The Pillars of Development of Knowledge-Based Economy, „Intercathedra”, No. 26, s. 182-185.

39. Widerska I. (2013), Podwyższenie wieku emerytalnego $w$ pracowniczym systemie emerytalnym - oczekiwania i zagrożenia, [w:] Gołembska E. (red.), Gospodarka globalna. Technologia. Spoleczeństwo, Wydawnictwo Uniwersytetu Ekonomicznego w Poznaniu, Poznań, s. 372-383.

40. Woszczyk P. (2013), Zarzadzanie wiekiem - ku wzrostowi efektywności organizacji, [w:] Woszczyk P., Czernecka M. (red.), CzłoWIEK to inwestycja. Podręcznik do zarzadzania wiekiem w organizacjach, HRP Group, Łódź, s. 33-53.

41. www.stat.gov.pl (dostęp: 30.10.2017).

42. www.zus.pl - Statystyka (dostęp: 13.12.2017).

43. Zięba K. (2014), Zarządzanie wiekiem - współczesne trendy w zarzadzaniu, [w:] Richert-Kaźmierska A., Stankiewicz K. (red.), Zarządzanie wiekiem $w$ przedsiębiorstwach sektora MSP - wybrane zagadnienia, Politechnika Gdańska, Wydział Zarządzania i Ekonomii, Gdańsk, s. 41-52.

44. ZUS (2013), Prognoza demograficzna, [w:] Prognoza wplywów i wydatków funduszu emerytalnego do 2060 roku, Zakład Ubezpieczeń Społecznych, Departament Statystyki i Prognoz Aktuarialnych, Warszawa. 
45. Żukowski M. (2006), Polski system emerytalny w kontekście Unii Europejskiej, [w:] Golinowska S., Boni M. (red.), Nowe dylematy polityki społecznej, CASE - Centrum Analiz Społeczno-Ekonomicznych, Warszawa, s. 181-185.

46. Żukowski M. (2012), Podwyższanie wieku emerytalnego $w$ perspektywie demografii i sytuacji na rynku pracy, [w:] Żukowski M., Malaka J. (red.), Wiek emerytalny, Polskie Stowarzyszenie Ubezpieczenia Społecznego, Kazimierz Dolny, s. 39-50.

47. Żukowski M., Szumlicz T. (2004), Systemy emerytalne w krajach Unii Europejskiej, Twigger, Warszawa.

\title{
SOLIDARITY, EQUIVALENCE OR JUSTICE? RETIREMENT AGE MANAGEMENT IN THE POLISH PUBLIC PENSION SYSTEM
}

\begin{abstract}
This paper attempts to analyze socio-economic determinants concerning the management of retirement age in the public pension system in Poland. The starting point for the discussion is the principle according to which the right to retirement is determined by reaching the specified age and by documenting the insurance period specified by law. The background for the analysis is the economic, demographic and legal and organizational conditions existing in Poland at the end of 2017, seen from the perspective of management sciences. Taking into account selected factors, including the length of the insurance period and the amount of capital accumulated by the insured, the questions about the equivalence, solidarity, and fairness of the public pension system in Poland were verified. Basing on the secondary data of OECD, GUS and ZUS public statistics, the authors applied selected methods of comparative and descriptive analysis. In conclusion, recommendations for social policy were formulated.
\end{abstract}

Keywords: social insurance, pension system, management of retirement age, Poland 